\title{
MAJELIS TAKLIM ASY SYIFA: POTRET MAJELIS TAKLIM DALAM KOMUNITAS MUSLIM MUALLAF DI BALI
}

\author{
Nyayu Khodijah \\ UIN Raden Fatah Palembang \\ nyayukhotijah@radenfatah.ac.id
}

\begin{abstract}
Asy Syifa's taklim assembly functions as an educational institution that provides basic religious teaching for its worshipers and the implementation is not much different from the learning process that takes place in schools / madrasas or in the Al-Qur'an Education Park (TPA). In the process of its implementation, this taklim assembly is strongly influenced by the socio-cultural and economic conditions of the congregation and its clerics. This can be seen from the selection of subject matter, learning process, and management. The subject matter chosen is the main material of Islamic teachings at the basic level. The learning process is dominated by teachers as a single learning resource. The management applied is a single management pattern, where the leader also serves as a secretary and treasurer of the taklim assembly.
\end{abstract}

Key words: Taklim Assemblies, Subject Matter, Learning Process

\begin{abstract}
Abstrak
Majelis taklim Asy Syifa menjalankan fungsi sebagai lembaga pendidikan yang memberikan pengajaran agama dasar bagi para jamaahnya dan penyelenggaraannya tidak jauh berbeda dengan proses pembelajaran yang berlangsung di sekolah/madrasah atau di Taman Pendidikan Al Qur'an (TPA). Dalam proses penyelenggaraannya, majelis taklim ini sangat dipengaruhi oleh kondisi sosial budaya dan ekonomi para jamaah dan ustaz/ahnya. Hal ini nampak dari pemilihan materi pelajaran, proses pembelajaran, dan manajemennya. Materi pelajaran yang dipilih adalah materi utama ajaran Islam pada level dasar. Proses pembelajarannya lebih banyak didominasi oleh guru sebagai sumber belajar tunggal. Manajemen yang diterapkan adalah pola manajemen tunggal, di mana pimpinan merangkap juga sebagai sekretaris dan bendahara majelis taklim.
\end{abstract}

Kata Kunci: Majelis Taklim, Materi Pelajaran, Proses Pembelajaran

\section{Pendahuluan}

Islam sebagai agama, sarat dengan makna-makna dan ajaran yang berhubungan erat dengan pendidikan. Berangkat dari hubungan antara makna Islam dengan pendidikan itulah maka para ahli pendidikan Islam telah merumuskan bahwa pendidikan Islam itu perlu dilihat dari dua sudut pandang, yaitu konsep pendidikan Islam secara umum dan konsep pendidikan Islam secara khusus. Jalaluddin menjelaskan bahwa secara umum konsep pendidikan Islam didasarkan kepada tiga faktor utama, yaitu: 1) hakikat penciptaan manusia yaitu agar manusia menjadi pengabdi Allah yang taat dan setia; 2) peran dan tanggung jawab manusia sejalan dengan statusnya selaku hamba Allah, al-Basyr, al-Insan, al-Nas, Bani Adam maupun Khalifah Allah; dan 3) tugas utama Rasul yaitu membentuk Akhlak yang mulia serta memberi rahmat bagi seluruh alam¹.

${ }^{1}$ Jalaluddin, Teologi Pendidikan Islam, (Jakarta: Raja Grafinda Persada, 2003), h.74. 
Ketiga faktor ini merupakan dasar berpijak bagi perumusan pendidikan Islam secara umum. Dalam konteks pendidikan yang demikian akan diperoleh pembinaan dan pengembangan potensi manusia (sumber daya insani) dalam posisinya sebagai hamba Allah, al-Basyr, al-Nas, maupun khalifah Allah. Dalam konteks peradaban pendidikan akan melahirkan pribadi manusia beriman dan beramal saleh sebagai hamba Allah.

Rumusan pendidikan yang umum tersebut, kemudian dihubungkan lagi oleh para pendidik Muslim, dengan merumuskan pendidikan Islam itu sebagai: "usaha membimbing dan mengembangkan potensi manusia, baik sebagai mahluk individu, makhluk sosial secara bertahap sesuai dengan tahap pertumbuhan dan perkembangannya" 2 . Berangkat dari rumusan yang demikian, konsep pendidikan Islam secara khusus terdiri dari:

1. Pendidikan harus berdasarkan tingkat pertumbuhan dan perkembangan peserta didik

2. Pendidikan harus berdasarkan jenis kelamin

3. Pendidikan harus berdasarkan tingkat kecerdasan

4. Pendidikan keluarga

5. Pendidikan harus berdasarkan kelembagaan yakni:

a. Kelembagaan formal seperti Madrasah maupun pesantren.

b. Kelembagaan non formal seperti Majelis Taklim, baik di Masjid atau pun di majelis lainnya ${ }^{3}$.

Secara konseptual, Majelis Taklim dapat diartikan sebagai tempat untuk melaksanakan kegiatan ceramah umum atau pengajian Islam. Kegiatan ini banyak dilakukan di Mesjid, di halaman Masjid atau juga di kantor-kantor, baik kantor pemerintah maupun swasta dan di tempat lain yang dikhususkan untuk itu. Majelis Taklim merupakan institusi pendidikan nonformal keagamaan, di mana prinsip kegiatannya adalah kemandirian dan swadaya masyarakat dari masing-masing anggotanya.

Dalam Ensiklopedi Islam, Majelis Taklim dilihat dari karakteristiknya secara umum adalah lembaga (institusi) yang melaksanakan pendidikan atau pengajian agama Islam, yang memiliki kurikulum, ustaz/guru, jama'ah, metode, materi dan tujuan pembelajaran4. Sementara itu, Departemen Agama RI menyatakan Majelis Taklim adalah lembaga pengajian Islam yang memiliki ciriciri tersendiri dilihat dari sudut metode dan buku pegangan yang digunakan, jama'ah, pengajar (ustaz) materi yang diajarkan, sarana dan tujuan ${ }^{5}$.

Majelis taklim merupakan lembaga pendidikan Islam non formal yang telah eksis sejak lama. Eksistensi majelis taklim sebagai salah satu bentuk lembaga pendidikan Islam non formal telah mendapat pengakuan dalam Undang-Undang RI nomor 20 Bab VI pasal 26 ayat 4 yang secara eksplisit

2 Ibid., h. 77.

${ }^{3}$ Ibid., h. 78.

${ }^{4}$ Dewan Redaksi, Ensiklopedi Islam, (Jakarta: Ichtiar Baru Van Hoeve, 2001), h.120-121.

${ }^{5}$ Depag, RI, Ensiklopedi Islam, (Jakarta, Depag RI, 1996), h. 675. 
menyebutkan Majelis Taklim sebagai bagian dari pendidikan nonformal. Hal ini menunjukkan bahwa Majelis Taklim merupakan salah satu bagian penting dari sistem pendidikan nasional.

Sebagai institusi pendidikan Islam yang berbasis masyarakat, peran strategis Majelis Taklim terutama terletak dalam mewujudkan learning society, yaitu suatu masyarakat yang memiliki tradisi belajar tanpa dibatasi oleh usia, jenis kelamin, tingkat pendidikan, juga dapat menjadi wahana belajar, serta menyampaikan pesan-pesan keagamaan, wadah mengembangkan silaturrahmi dan berbagai kegiatan kegamaan lainnya bagi semua lapisan masyarakat.

Sebagai bagian dari Sistem Pendidikan Nasional, Majelis Taklim melaksanakan fungsinya pada tataran nonformal, lebih fleksibel, terbuka dan merupakan salah satu solusi yang seharusnya memberikan peluang kepada masyarakat untuk menambah dan melengkapi pengetahuan yang kurang atau tidak sempat mereka peroleh pada pendidikan formal, khususnya dalam aspek keagamaan.

Sebagai lembaga dakwah sekaligus wadah pembinaan ummat Majelis Taklim mempunyai beberapa fungsi diantaranya: 1) wadah untuk menyampaikan pesan-pesan keagamaan kepada jamaahnya; 2) wadah yang memberi peluang kepada jama'ah untuk tukar menukar pikiran, berbagi pengalaman, dalam masalah keagamaan; 3) wadah yang dapat membina keakraban di antara sesama jama'ahnya; dan 4) wadah informasi dan kajian keagamaan serta kerjasama di kalangan ummat ${ }^{6}$.

Pentingnya Majelis Taklim bagi komunitas muslim tentu tidak diragukan lagi. Dengan memperhatikan perkembangan dan eksistensi Majelis Taklim, maka Majelis Taklim sebagai lembaga pendidikan nonfomal pada masa sekarang ini mempunyai kedudukan tersendiri dalam mengatur pelaksanaan pendidikan agama dalam rangka dakwah Islamiyah dan merupakan salah satu alat bagi pelaksanaan pendidikan seumur hidup (long life education).

Dalam menjalankan fungsinya tersebut, karena sifatnya non formal, maka penyelenggaraan majelis taklim dalam beragam bentuknya berjalan sesuai dengan kondisi sosiokultural dan ekonomi masyarakat. Bahkan bisa dikatakan bahwa penyelenggaraan majelis taklim tidak terlepas dari kebutuhan masyarakat yang menjadi jamaahnya. Karena itu kemudian muncul berbagai karakteristik majelis taklim yang tumbuh dan berkembang dalam masyarakat dalam jumlah yang tidak sedikit.

Akan tetapi dalam perjalanannya, tumbuh dan berkembangnya beragam Majelis Taklim tersebut belum diikuti dengan sentuhan manajerial yang memadai, sehingga Majelis Taklim dan kegiatannya cenderung berjalan dalam ritme yang monoton tanpa inovasi, mencerminkan kelompok-kelompok belajar yang bersifat rutinitas, kurang menyentuh terhadap realitas kehidupan yang dialami oleh jama'ah, serta kurang berdaya memberikan kontribusi dalam

${ }^{6}$ Rosehan, dkk, 2002, h. v 
membantu dan menyiapkan jama'ahnya menghadapi tantangan hidup yang semakin kompetitif.

Menyadari pentingnya posisi Majelis Taklim sebagai lembaga pendidikan Islam nonformal dan menyadari pula adanya keterkaitan antara majelis taklim dan kondisi sosokultur dan ekonomi masyarakat pendukungnya, penelitian ini dipandang sangat penting. Karena untuk mengembangkan dan memberdayakan Majelis Taklim, diperlukan kajian dan analisis yang lebih komprehensif tentang karakteristik Majelis Taklim dan masyarakat pendukungnya. Pemahaman tentang karakteristik ini, selanjutnya menjadi acuan untuk mereposisi dan memetakan kembali eksistensi Majelis Taklim, sehingga lebih memiliki fungsi dan kontribusi yang lebih maksimal dalam rangka pembangunan masyarakat muslim.

Berdasarkan latar belakang di atas, maka masalah penelitian yang diangkat adalah: Apakah kondisi sosiokultural dan ekonomi masyarakat memberi warna terhadap Majelis Taklim Asy Syifa menyangkut fungsi yang dijalankan, manajemen, materi, dan proses pembelajarannya. Penelitian ini bertujuan untuk memperoleh data maupun informasi yang lengkap, mendalam, dan komprehensif tentang: fungsi yang dijalankan, manajemen, materi, dan proses pembelajaran pada Majelis Taklim Asy Syifa.

\section{Metodologi Penelitian}

Penelitian ini dilakukan dengan menggunakan pendekatan kualitatif dengan metode fenomenologik. Pendekatan dan metode ini dipilih dengan pertimbangan guna memperoleh pemahaman yang mendalam tentang karakteristik dan fenomena sosial jama'ah Majelis Taklim. Dengan pendekatan kualitatif memungkinkan peneliti menggali pengalaman subjek secara lebih mendalam ${ }^{7}$.

Penelitian ini dilakukan di Majelis Taklim Asy-Syifa yang berada di Kota Denpasar, Bali. Pemilihan majelis taklim Asy-Syifa sebagai sasaran penelitian didasarkan pada pertimbangan: 1) telah terdaftar di Kantor Dep. Agama Kota Denpasar maupun Kanwil Dep. Agama Propinsi Bali; 2) menyelenggarakan pengajian secara rutin sekali seminggu; 3) memiliki jama' ah lebih dari 40 orang; serta 4) meski belum lama berdiri, akan tetapi majelis taklim ini memiliki keunikan dibandingkan majelis taklim lain yang ada, baik di propinsi Bali sendiri maupun di daerah lainnya, karena anggotanya adalah para wanita muslimah muallaf.

Sumber data dalam penelitian ini: 1) informan kunci (key informant), yaitu: para pengurus, jama'ah, dan muballigh/ghah Majelis Taklim; serta 2) informan pelengkap, yang diperlukan untuk lebih melengkapi data yang belum atau tidak dapat diperoleh dari informan kunci. Informan pelengkap dapat juga berfungsi sebagai klarifikasi/ cross check data yang diperoleh dari informan kunci. Informan

${ }^{7}$ Reinhartz,1992 
pelengkap dalam hal ini adalah para pejabat di Kantor Wilayah Departemen Agama dan Tokoh Agama di propinsi Bali. Untuk menentukan sumber data (informan) ini digunakan teknik snowball, artinya informan pertama diminta untuk menunjukkan informan berikutnya, begitulah seterusnya sehingga diperoleh informasi yang cukup.

Teknik pengumpulan data yang digunakan adalah observasi, wawancara, dan studi dokumentasi. Observasi yang digunakan dalam penelitian ini adalah jenis participant observation (pengamatan partisipatif). Dalam hal ini, pengamatan partisipatif ini dilakukan guna menggali data tentang proses pembelajaran (materi dan metode) pada sampel Majelis Taklim Asy Syifa. Hasilnya, dituangkan dalam bentuk catatan lapangan. Wawancara digunakan untuk menggali data tentang manajemen dan materi pembelajaran. Wawancara dilakukan kepada pengurus Majelis Taklim, jama'ah, serta ustaz/guru. Teknik wawancara yang digunakan adalah wawancara bebas terpimpin, di mana pewawancara membawa kerangka pertanyaan (framework of questions) untuk diajukan, namun bagaimana teknik dan timing (waktu) pertanyaan diajukan sepenuhnya diserahkan kepada kebijakan pewawancara. Studi dokumentasi dilakukan terhadap semua sumber-sumber dokumen yang dapat memberikan data dan informasi tentang kondisi sosial ekonomi masyarakat serta jumlah majelis taklim yang ada di propinsi Bali, khususnya di Kota Denpasar, baik yang bersumber dari BPS Propinsi, BPS Kota, maupun Kanwil Departemen Agama Propinsi Bali.

Teknik analisis data yang dipergunakan adalah teknik analisis deskriptif kualitatif, dengan tahap-tahap: 1) reduksi data, yakni data yang telah terkumpul melalui observasi, wawancara dan studi dokumentasi direduksi sedemikian rupa sehingga tidak ada lagi data yang dianggap tidak sesuai dengan masalah dan tujuan penelitian; 2) penyajian data, yakni data yang teleh direduksi kemudian disajikan apa adanya. Jika diperlukan, untuk data yang memiliki kompleksitas tinggi digunakan tabulasi distribusi frekuensi guna lebih mudah dibaca, dipahami, dan diinterpretasi; 3) interpretasi data, yakni data yang telah disajikan diberi pemaknaan dengan interpretasi sedemikian rupa sehingga dapat dipahami maksudnya; dan 4) penarikan kesimpulan, yakni berdasarkan interpretasi data yang dilakukan lalu ditarik kesimpulan yang berkaitan dengan masalah dan tujuan penelitian.

\section{Hasil Penelitian}

\section{Gambaran Umum Kota Denpasar}

Kota Denpasar adalah ibukota Propinsi Bali dengan luas wilayah sebesar $12.778 \mathrm{Ha}$ atau hanya sekitar 2,18 \% dari luas wilayah Propinsi Bali8. Secara

8 Denpasar dalam Angka, 2009, h.1 
administratif, kota Denpasar terbagi menjadi tiga kecamatan, yaitu: Denpasar Barat, Denpasar Timur, dan Denpasar Selatan9.

Berdasarkan Supas Juni 2008, penduduk kota Denpasar berjumlah 574.955 jiwa, yang terdiri dari penduduk laki-laki 292.087 jiwa $(50,81 \%)$ dan penduduk perempuan 282.868 jiwa $(49,19 \%)^{10}$. Dibandingkan dengan luas wilayahnya, maka angka kepadatan penduduk kota Denpasar telah mencapai 4.500 jiwa per $\mathrm{km}^{2}$. Angka ini merupakan angka kepadatan tertinggi di Propinsi Bali11. Sementara itu, untuk Rasio Jenis Kelamin (perbandingan jumlah penduduk lakilaki per 100 penduduk perempuan) di Kota Denpasar menunjukkan angka sebesar 106, yang merupakan angka rasio jenis kelamin tertinggi di Propinsi Bali $^{12}$.

Mata pencaharian sebagian besar penduduk kota Denpasar adalah di sektor perdagangan, hotel dan restoran (38,95\%) serta jasa-jasa (28,4\%). Selebihnya, 12,9\% bekerja di sektor industri, 6,22\% di sektor angkutan dan komunikasi, 5,98\% di sektor bangunan/konstruksi, 5,04\% di sektor keuangan, serta hanya 2,05\% yang bekerja di sektor pertanian dan 0,47\% di sektor listrik, gas, dan air minum ${ }^{13}$. Kondisi ini bisa dimaklumi karena kota Denpasar adalah ibukota propinsi Bali yang merupakan salah satu daerah tujuan wisata terkenal di Indonesia.

Dilihat dari komposisi agama, mayoritas penduduk kota Denpasar beragama Hindu, yaitu sebanyak 319.979 orang atau 63,41 \% dari seluruh penduduk. Selebihnya memeluk agama Katholik 13.940 orang $(2,76 \%)$, memeluk agama Protestan 26.677 orang (5,29\%), dan memeluk agama Budha 12.182 orang $(2,41 \%)$. Sementara yang memeluk agama Islam sebanyak 131.846 orang (26, $13 \%)^{14}$. Data tentang jumlah umat Islam dari BPS ini sangat jauh berbeda dengan data dari Bidang Kependais Kanwil Depag Propinsi Bali yang menyatakan bahwa jumlah umat Islam di Kota Denpasar hanyalah 63.723 orang15.

Sementara itu, jumlah sarana ibadah (tempat peribadatan) di kota Denpasar mencapai 263 buah, meliputi sarana ibadah umat Hindu sebanyak 106 buah (40,3\%), Islam berjumlah 109 buah (41,44\%), Katholik berjumlah 3 buah $(1,14 \%)$, Protestan berjumlah 39 buah $(14,83 \%)$, dan Budha berjumlah 6 buah $(2,28 \%)$. Jumlah masing-masing jenis tempat ibadah lima tahun terakhir selengkapnya dapat dilihat pada tabel 1.

Dilihat dari jumlah pemuka/tokoh agama yang ada di Kota Denpasar, pemuka agama Hindu berjumlah 360 orang, pemuka agama Budha berjumlah 12 orang, pemuka agama Islam berjumlah 123 orang, pemuka agama Katholik

\footnotetext{
9 Bali dalam Angka, 2009, h. 37

${ }^{10}$ Denpasar dalam Angka, 2009, h. 28

11 Denpasar dalam Angka, 2009, h. 29

12 Bali dalam Angka, 2009, h.50

13 Denpasar dalam Angka, 2006, h.42

14 Denpasar dalam Angka, 2006, h.58-59

15 Rekapitulasi Data Penamas, 2006
} 
berjumlah 25 orang, dan pemuka agama Protestan berjumlah 49 orang. Rincian jumlah pemuka agama selengkapnya dapat dilihat pada Tabel 2.

Dilihat dari lembaga pendidikan yang ada, jumlahnya cukup banyak, yaitu Taman Kanak-kanak (TK) berjumlah 177 buah, Sekolah Dasar (SD) berjumlah 211 buah, SLTP berjumlah 44 buah, SLTA berjumlah 46 buah, dan Perguruan Tinggi berjumlah 26 buah. Keadaan lembaga pendidikan di Kota Denpasar selengkapnya dapat dilihat pada Tabel 3.

Tabel 1. Jumlah Tempat Ibadah di Kota Denpasar Tahun 2001-2005

\begin{tabular}{|l|c|c|c|c|c|}
\hline \multicolumn{1}{|c|}{ Tempat Ibadah } & 2001 & 2002 & 2003 & 2004 & 2005 \\
\hline Kahyangan Tiga & 105 & 105 & 105 & 105 & 105 \\
Sad\&Dang Kahyangan & 1 & 1 & 1 & 1 & 1 \\
Kahyangan Lainnya & - & - & - & - & - \\
Masjid & 26 & 26 & 26 & 26 & 26 \\
Langgar & 7 & - & - & - & - \\
Musholla & 73 & 83 & 83 & 83 & 83 \\
Gereja Katolik & 3 & 3 & 3 & 3 & 3 \\
Kapel & - & - & - & - & - \\
Gereja Protestan & 39 & 39 & 39 & 39 & 39 \\
Wihara & 4 & 6 & 6 & 6 & 6 \\
\hline
\end{tabular}

Sumber: Denpasar dalam Angka, 2006: 206

Tabel 2. Jumlah Pemuka Agama di Kota Denpasar

Tahun 2001-2005

\begin{tabular}{|l|l|c|c|c|c|c|}
\hline \multicolumn{1}{|c|}{ Agama } & Pemuka Agama & 2001 & 2002 & 2003 & 2004 & 2005 \\
\hline Hindu & Pendeta & 104 & 119 & 53 & 53 & 111 \\
& Pemangku & 3.097 & 1.717 & 249 & 249 & 249 \\
& Jumlah & 3.201 & 1.013 & 302 & 302 & 360 \\
\hline Budha & Bhiksu & 2 & 6 & 3 & 3 & 3 \\
& Uparaka & 2 & 2 & 9 & 9 & 9 \\
& Jumlah & 4 & 8 & 12 & 12 & 12 \\
\hline Islam & Khatib & 85 & 85 & 68 & 68 & 68 \\
& Mubaligh & 27 & 27 & 34 & 34 & 34 \\
& Jumlah & 121 & 121 & 123 & 123 & 123 \\
\hline Katholik & Pastur & 9 & 9 & 9 & 9 & 9 \\
& Brod & 1 & 1 & 1 & 1 & 1 \\
& Suster & 15 & 15 & 15 & 15 & 15 \\
& Jumlah & 25 & 25 & 25 & 25 & 25 \\
\hline Protestan & Pendeta & 49 & 49 & 49 & 49 & 49 \\
\hline
\end{tabular}

Sumber: Denpasar dalam Angka, 2006: 209-210 
Tabel 3. Keadaan Lembaga Pendidikan di Kota Denpasar Tahun 2005

\begin{tabular}{|l|c|c|c|c|}
\hline Lembaga Pendidikan & Negeri & Swasta & Jumlah Murid & Jumlah Guru \\
\hline TK & 1 & 176 & 14.396 & 882 \\
SD & 179 & 29 & 74.564 & 2.920 \\
SLTP & 11 & 33 & 26.469 & 1.915 \\
SLTA & 12 & 34 & 123.627 & 2.331 \\
Perguruan Tinggi & 8 & 18 & 26.626 & 2.505 \\
\hline & 111 & 290 & 265.682 & 10.553 \\
\hline
\end{tabular}

Sumber: Denpasar dalam Angka 2006: 53-54

Selain lembaga pendidikan yang telah disebutkan di atas, juga terdapat berbagai lembaga pendidikan agama sebanyak 63 buah. Dari jumlah tersebut, 47 buah diantaranya adalah lembaga pendidikan Islam, yang terdiri dari 17 buah Raudlatul Atfal (RA), 6 buah MI, 2 buah MTs, 4 buah pondok pesantren, dan 18 buah Madrasah Diniyah"16. Di luar lembaga pendidikan yang sudah disebutkan di atas, berdasarkan data Bidang Kependais Kanwil Depag Propinsi Bali, juga terdapat 47 buah Taman Pendidikan Al-Qur'an dan 50 buah majelis taklim.

Berdasarkan data yang telah dipaparkan di atas, nampak bahwa umat Islam di Kota Denpasar adalah termasuk kelompok minoritas. Hal ini dimaklumi jika kemudian ada keinginan untuk senantiasa menjalin silaturahmi di kalangan sesama umat Islam. Keinginan ini kemudian disalurkan dengan membentuk berbagai jenis majelis taklim. Menurut Kasi Penamas Bidang Kependais Kanwil Depag Propinsi Bali, sebagian besar majelis taklim yang terbentuk di propinsi Bali adalah didasarkan pada keinginan untuk menjalin silaturahmi dikarenakan adanya rasa persamaan nasib. Karena itu, ada majelis taklim untuk kalangan muallaf, ada majelis taklim untuk kalangan pedagang asongan, bahkan ada majelis taklim yang dibentuk oleh kalangan janda muslim. Menurut salah seorang pengurus majelis taklim, keberadaan majelis taklim tersebut tidak hanya sekedar berfungsi mengembangkan wawasan keagamaan para anggotanya, akan tetapi juga menjadi ajang silaturrahmi dan kerjasama dalam membantu anggota yang mengalami kesulitan.

\section{Keunikan Majelis Taklim Asy Syifa}

Majelis Taklim Asy Syifa berada di Kota Denpasar atau lebih tepatnya di Jl. Raya Puputan III N0. 46 Kecamatan Denpasar Timur, Denpasar Bali, Kode Pos 80235. Berbeda dengan kebanyakan majelis taklim lain yang tersebar di seluruh Nusantara yang berfungsi sebagai lembaga dakwah, majelis taklim Asy Syifa ini memiliki keunikan tersendiri. Sesuai dengan namanya, yaitu Pengajian Muallaf Asy Syifa, anggota majelis taklim ini semuanya adalah para muslimah muallaf yang notabene belum banyak mengetahui ajaran Islam. Karenanya, keberadaan

${ }^{16}$ Denpasar dalam Angka, 2006, h. 85-86 
majelis taklim ini lebih banyak berfungsi sebagai lembaga pendidikan yang memberikan pengajaran agama dasar bagi para anggotanya.

Seperti diketahui bahwa pendirian sebagian besar majelis taklim yang tersebar di nusantara dilatarbelakangi oleh keinginan untuk membentuk wadah tukar menukar pikiran, berbagai pengalaman dalam masalah keagamaan dan wadah pembinaan keakraban dan kerjasama umat. Khusus di propinsi Bali, sebagian besar majelis taklim berdiri karena dilatarbelakangi oleh keinginan membentuk wadah untuk menjalin silaturrahmi di kalangan masyarakat muslim. Berbeda dengan kedua latar belakang tersebut, pendirian majelis taklim yang juga dipimpin oleh seorang muslimah muallaf ( $\mathrm{Hj}$. Wayan Kusmary Bram) ini dilatarbelakangi oleh keprihatinan pendirinya (Hj. Sri Drajati Suyono) dan Hj. Wayan Kusmary Bram atas nasib para muallaf muslimah yang tidak mendapatkan pendidikan agama yang cukup dari suami mereka. Karena itu, kebanyakan dari para muallaf tersebut apabila ditinggal mati atau dicerai oleh suami mereka yang pada mulanya menarik mereka untuk memeluk agama Islam, mereka dapat kembali ke agama semula yaitu Hindu. Menurut penuturan ketua Majelis Taklim Asy Syifa: "Pengajian ini didirikan karena dilatarbelakangi oleh visi misi kita agar supaya para muallaf apabila ditinggal suami, baik ditinggal mati, dicerai, atau diterlantarkan, tetap istiqomah dalam kondisi iman dan Islam" 17.

\section{Sejarah Singkat Majelis taklim Asy Syifa}

Majelis taklim Asy Syifa didirikan pada 6 Maret 2005, diprakarsai oleh Hj. Sri Drajati Suyono, salah seorang tokoh masyarakat Muslim di Bali. Sebagai tokoh yang memiliki perhatian yang besar terhadap kondisi masyarakat muslim di propinsi Bali, beliau menyambut baik atas masukan yang disampaikan oleh Hj. Wayan Kusmary Bram untuk membentuk pengajian yang menampung para muslimah muallaf guna mempelajari ajaran Islam.

Berdasarkan pengalaman Hj Wayan Kusmary Bram, sebagian besar muallaf di Bali, khususnya di Kota Denpasar, tidak memiliki pengetahuan dan pemahaman yang cukup tentang ajaran Islam sehingga mereka tidak dapat mengamalkannya secara benar. Sebagai contoh, bagaimana mungkin mereka dapat melaksanakan sholat yang benar jika mereka tidak tahu bacaan, syarat, dan rukunnya. Selain itu, untuk mempelajari bacaan sholatpun mereka tidak bisa membaca huruf Arab dan mengaji. Kekurangan pengetahuan tersebut, diperparah lagi dengan ketidakpedulian para suami mereka. Seperti yang dicontohkan oleh salah seorang anggota yang berpendidikan sarjana dan telah masuk Islam \pm 9 tahun, meski suaminya adalah seorang guru ngaji akan tetapi ia tidak pernah diajari mengaji dengan alasan ketidakcocokan dengan cara mengajar suaminya.

17 Wawancara tanggal 29 Januari 2009 
Melihat pengalaman para muallaf tersebut, $\mathrm{Hj}$. Sri Drajati Suyono merasa terketuk hatinya untuk membentuk pengajian bagi para muallaf. Pendirian majelis taklim ini bertujuan untuk: menjaga dan mempertahankan keimanan dan memperdalam wawasan keislaman para jamaahnya, sehingga mereka mampu memahami dan melaksanakan konsep kesalehan ritual dan kesalehan sosial secara benar. Hj. Sri Drajati Suyono sendiri, selain bertindak sebagai pelopor pendirian majelis taklim ini, ia juga menyediakan tempat dan sebagai donatur tunggal bagi terlaksananya pengajian tersebut.

Sejak didirikan hingga sekarang, majelis taklim yang dipimpin oleh $\mathrm{Hj}$. Wayan Kusmary ini belum pernah mengalami pergantian kepengurusan. $\mathrm{Hj}$ Wayan Kusmary sendiri adalah penduduk asli Bali yang dilahirkan di Denpasar tanggal 26 Juni 1960. Wanita yang sehari-harinya bermatapencaharian sebagai wirausahawati ini hanya lulusan SLTA. Dalam kepemimpinan beliau, hingga saat ini majelis taklim ini telah membina anggota sebanyak \pm 100 orang, namun yang aktif hanya sekitar $50 \%$ karena alasan transportasi dan ekonomi. Berdasarkan keterangan beliau, sebagian jamaah majelis taklim ini termasuk golongan ekonomi menengah ke bawah, meski tidak sedikit diantaranya adalah termasuk berkecukupan.

\section{Ketenagaan}

Tenaga tetap yang mengajar di majelis taklim Asy Syifa ini ada 2 orang, yang kesemuanya perempuan. Selain itu, juga ada tiga orang tenaga pengajar tidak tetap yang semuanya laki-laki. Usia ustaz/ustazah berkisar antara $35-44$ tahun. Tingkat pendidikan semua ustaz/ustazah adalah S1 Perguruan Tinggi Agama Islam.

Kondisi sosial ekonomi sebagian besar ustaz/ustazah tergolong menengah ke bawah dan bekerja sebagai PNS, dua diantaranyanya adalah Hakim Pengadilan Tinggi Agama dan Kasi Penamas Bidang Kependais Kanwil Depag Propinsi Bali. Tempat tinggal mereka berada cukup jauh dari lokasi penyelenggaraan pengajian, dengan jarak terjauh $10 \mathrm{~km}$. Dengan tugas mengajar 4 kali sebulan, para ustaz/ustazah ini mendapat insentif sebesar Rp. 400.000,/bulan.

\section{Kurikulum dan Materi}

Sebagai lembaga pendidikan non formal, kurikulum yang digunakan oleh majelis taklim Asy Syifa ini tidak tersusun secara rinci seperti halnya kurikulum di sekolah, akan tetapi hanya berupa daftar materi pelajaran yang diajarkan, dan materinya pun tidak tersusun secara rinci, akan tetapi tergantung pada ustaz/ah akan mengajarkan apa.

Pokok materi yang diajarkan terdiri dari: membaca Al-Qur'an, Tajwid, Fiqih, Tauhid, Akhlak, Tafsir, dan Tarikh. Dilihat dari levelnya, materi-materi yang diajarkan tersebut masih bersifat dasar. Selain materi pokok tersebut, 
materi lain yang diajarkan akan tetapi hanya bersifat tambahan dan insidental adalah membaca do'a dan qasidahan. Satu-satunya alasan mengapa materimateri tersebut dipilih adalah karena dibutuhkan oleh para jamaah. Menurut salah seorang ustazah, materi apa yang hendak diajarkan biasanya ditentukan oleh ustaz/ustazah dengan terlebih dahulu dibicarakan dengan pengurus majelis taklim.

Buku/kitab yang digunakan cukup beragam, tergantung pada buku/kitab yang dimiliki oleh para ustaz/ustazah. Buku/kitab yang digunakan diantaranya adalah: buku/kitab Fiqih Islam yang ditulis oleh Sulaiman Rasyid, Al-Fiqhul Islamiyyu wa Adillatuhu yang ditulis oleh DR. Wahbah AzZuhaily, Riyadhush Sholihin, Aqidah Akhlak, dan Sejarah Kebudayaan Islam. Buku-buku/kitab-kitab tersebut hanya merupakan kitab pegangan guru. Buku/kitab yang menjadi pegangan jamaah tidak ditentukan secara khusus. Artinya, bagi jamaah yang telah memiliki buku/kitab yang sesuai mereka dapat menggunakannya, akan tetapi jika mereka belum memiliki boleh memfotocopi. Bedasarkan observasi yang dilakukan, diketahui bahwa tidak semua jamaah memiliki buku pegangan untuk setiap materi yang diajarkan.

\section{Proses Pembelajaran}

Proses pembelajaran pada majelis taklim Asy Syifa ini berpusat di rumah pelopornya, yaitu rumah Hj. Sri Drajati Suyono. Waktu penyelenggaraan pembelajarannya sekali seminggu, yaitu pada hari Sabtu selama 2 jam, sejak pukul 14.00 hingga 16.00 WITA. Dalam hal ini, para jamaah dibagi menjadi dua kelas, yaitu kelas A untuk jamaah yang berada pada tingkat dasar dan kelas B untuk jamaah yang sudah berada pada tingkat mahir. Disamping itu, bagi para pemula juga disediakan program pembelajaran lain yang dinamakan program kejar paket. Materi tunggal yang diajarkan pada program ini adalah cara membaca Al-Qur'an tingkat dasar.

Berdasarkan hasil observasi diketahui bahwa proses pembelajaran yang terjadi di majelis taklim ini layaknya seperti dalam proses pembelajaran di sekolah/madrasah atau TPA (Taman Pendidikan Al-Qur'an). Para jamaah duduk lesehan secara paralel menghadap ustaz/ustazah dengan meja kayu panjang di hadapan mereka. Guru/ustaz merupakan satu-satunya sumber belajar sehingga sistem pembelajarannya lebih banyak berpusat pada guru/ustaz (teacher-centered). Metode penyampaian materi pelajaran yang dominan digunakan adalah metode ceramah. Namun penggunaan metode lebih banyak disesuaikan dengan jenis materi yang disampaikan. Guna meningkatkan pemahaman dan penguasaan materi, biasanya para ustaz/ustazah menerapkan tanya jawab, hafalan, latihan, dan praktek/demonstrasi. Untuk materi-materi yang tingkat kesulitannya tinggi, biasanya juga diberikan tugas. Khusus materi membaca Al-Qur'an, lebih banyak diterapkan metode latihan. Tujuannya adalah 
agar para jamaah lebih cepat menguasai pelajaran dan jika terdapat kesalahan dalam bacaan jamaah dapat segera diperbaiki.

Proses pembelajaran lebih banyak bersifat pasif karena para jamaah menerima begitu saja apa yang ajarkan kepada mereka tanpa sikap kritis. Meski demikian, otoritas ustaz/ah tidak begitu menonjol karena beberapa jamaah yang duduk di bagian belakang dapat saja mengobrol bahkan tidur-tiduran pada saat jam belajar tanpa mendapat teguran dari ustaz/ah.

Proses pembelajarannya diawali dengan membaca doa bersama yang dipimpin oleh salah seorang ustaz/ustazah, kemudian jamaah dipisah menjadi dua kelas dan masing-masing diajar dalam ruang terpisah oleh satu ustaz/ustazah. Setelah satu jam, ustaz/ustazah bergantian kelas yang diajar. Proses pembelajaran berlangsung tanpa alat bantu lain selain buku/kitab atau foto copi buku/kitab. Setelah selesai belajar, diadakan sholat ashar berjamaah yang dipimpin oleh salah seorang ustaz/ustazah.

\section{Jamaah}

Jamaah yang tercatat ada \pm 100 orang, tidak adanya jumlah yang pasti dikarenakan sistem administrasi pencatatannya bersifat non formal, siapa pun dan kapan pun dapat menjadi jamaah tanpa harus memenuhi syarat tertentu. Persyaratannya hanyalah ia adalah muslimah muallaf yang berkeinginan mendalami ajaran Islam.

Usia sebagian besar jamaah berkisar antara 25-44 tahun, hanya sebagian kecil (2 orang) yang berusia di atas 50 tahun. Tingkat pendidikan mereka pun beragam, ada yang tamat SLTA, SLTP, dan ada juga yang hanya tamat SD. Dari segi kondisi sosial ekonomi, sebagian besar jamaah (90\%) adalah tergolong ekonomi lemah.

Karena semua jamaah adalah para muallaf, maka motivasi utama mereka adalah untuk mengetahui ajaran Islam. Selain itu, menurut salah seorang jamaah yang telah menjadi jamaah sejak awal berdirinya majelis taklim ini, melalui majelis taklim ini mereka juga dapat menjalin silaturrahmi dengan para muslimah yang senasib dengan mereka.

\section{Pembahasan}

Sebagai lembaga pendidikan non formal, keberadaan sebuah majelis taklim tidak terlepas dari kebutuhan masyarakat pendirinya. Berdasarkan kebutuhan inilah kemudian majelis taklim menjalankan fungsinya. Begitu pun dengan majelis taklim Asy Syifa. Majelis taklim ini berdiri didasarkan pada kebutuhan yang dirasakan oleh masyarakat muslim di Bali khususnya di kota Denpasar.

Seperti diketahui bahwa masyarakat muslim di Bali tergolong masyarakat minoritas. Kondisi ini yang menyebabkan mereka mengalami keterbatasan dalam mempelajari ajaran Islam secara mudah. Karenanya, menurut Kabid Kependais Kanwil Depag Propinsi Bali, tidak jarang hal-hal yang dianggap biasa 
dan wajar dilakukan di propinsi lain yang mayoritas muslim menjadi hal yang tidak wajar di sini, misalnya penggunaan loudspeaker pada saat adzan tidak diperkenankan karena dianggap mengganggu ketenangan.

Merasa tidak leluasa dalam beribadah dan mempelajari agama, menimbulkan kebutuhan untuk saling mendukung dan bekerja sama antar sesama umat Islam di Bali. Guna terhindar dari prasangka negatif terhadap upaya tersebut, maka dipilihlah lembaga yang mendapat pengakuan legal, yaitu majelis taklim. Karena itu, tumbuh dan berkembangnya majelis taklim di Bali tidak terlepas dari kebutuhan masyarakat muslim untuk saling bersilaturrahmi dan bekerja sama. Dalam rangka untuk bersilaturrahmi dan bekerja sama inilah majelis taklim Asy Syifa lahir dan eksis.

Ada beberapa hal yang menarik yang menjadi karakteristik khas pada majelis taklim ini, yaitu fungsi yang dijalankan majelis taklim, kondisi sosial budaya dan ekonomi para jamaah dan ustaz/ahnya, serta manajemen penyelenggaraannya. Dalam hal fungsi yang dijalankan, tidak seperti kebanyakan majelis taklim lain yang berfungsi sebagai lembaga dakwah atau wadah untuk memperluas wawasan keislaman bagi para jamaahnya, majelis taklim Asy Syifa ini lebih berfungsi sebagai lembaga pendidikan yang memberikan pengajaran agama dasar bagi para jamaahnya. Sehingga penyelenggaraan yang dilakukan tidak jauh berbeda dengan proses pembelajaran di sekolah/madrasah atau di Taman Pendidikan Al Qur'an (TPA).

Dalam hal kondisi sosial budaya dan ekonomi para jamaah, berbeda dengan majelis taklim lain yang terdapat di propinsi Bali, khususnya di Kota Denpasar, yang para jamaahnya adalah penduduk pendatang dari pulau Jawa, maka jamaah majelis taklim ini semuanya adalah penduduk asli Bali yang muallaf dan sebagian besar berpenghasilan menengah ke bawah. Kondisi jamaah yang muallaf mempengaruhi pemilihan materi pelajaran yang diberikan. Seperti telah dikemukakan bahwa materi-materi yang diajarkan pada majelis taklim ini mencakup membaca Al-Qur'an, Tajwid, Fiqih, Tauhid, Akhlak, Tafsir, dan Tarikh. Jika dilihat dari pemilihan materi tersebut jelas nampak merupakan materi-materi utama dalam ajaran Islam yang harus dipahami oleh setiap orang yang mengaku dirinya muslim/ah. Selain itu, pada materi-materi tertentu yang luas cakupannya seperti Fiqih dan Tauhid, yang diajarkan hanya yang bersifat dasar saja, belum menyentuh pada hal-hal yang bersifat kajian mendalam. Hal ini dimaklumi karena semua jamaah majelis taklim ini adalah para muslimah muallaf yang tidak memiliki pengetahuan sama sekali tentang ajaran Islam.

Dalam hal kondisi sosial budaya dan ekonomi para ustaz/ah, semua ustaz/ah majelis taklim Asy Syifa ini adalah penduduk pendatang dari pulau Jawa, lulusan S1 PTAI, dan dengan status sosial ekonomi menengah ke atas. Perekrutan tenaga ustaz/ah yang berpendidikan S1 dimaklumi karena pendiri dan pengurus majelis taklim ini beranggapan bahwa karakteristik ustaz/ah yang demikian mampu menjamin para jamaah mendapatkan pelajaran yang benar 
dan dari sumber yang terpercaya. Namun hal ini akhirnya berpengaruh pada proses pembelajaran yang lebih banyak didominasi oleh para ustaz/ah, dan para jamaah lebih banyak bersifat pasif. Meski demikian, tidak menjamin para ustaz/ah memiliki otoritas kuat dalam proses pembelajaran. Hal ini tampak dari adanya jamaah yang mengobrol bahkan tidur-tiduran pada saat jam belajar tanpa mendapat teguran dari ustaz/ah. Hal ini dimungkinkan karena usia para ustaz/ah itu relatif masih cukup muda, sementara sebagian jamaah sudah berusia lanjut.

Kondisi sosial ekonomi para ustaz/ah yang termasuk golongan menengah ke atas, ditambah lagi kondisi sosial ekonomi pengurus yang juga sama, mempengaruhi manajemen penyelenggaraan majelis taklim ini. Hasil wawancara menunjukkan bahwa manajemen penyelenggaraan hanya dijalankan oleh satu orang saja, yaitu pimpinan sekaligus merangkap sebagai sekretaris dan bendahara. Pola manajemen tunggal yang demikian menyebabkan sistem administrasinya menjadi kurang rapi. Hal ini nampak dari tidak adanya dokumentasi jadwal materi, data jamaah, dan catatan keuangan majelis taklim. Kondisi sosial ekonomi para ustaz/ah pada akhirnya juga mempengaruhi penentuan jumlah insentif mereka yang relatif cukup tinggi, dengan sekali mengajar Rp. 100.000,-. Dana untuk insentif para ustaz/ah ini diperoleh dari pendiri majelis taklim sendiri sebagai donatur tunggalnya.

\section{Simpulan}

Majelis taklim Asy-Syiifa lahir untuk memenuhi kebutuhan para muslimah muallaf. Karenanya majelis taklim ini menjalankan fungsi sebagai lembaga pendidikan yang memberikan pengajaran agama dasar bagi para jamaahnya dan penyelenggaraannya tidak jauh berbeda dengan proses pembelajaran yang berlangsung di sekolah/madrasah atau di Taman Pendidikan Al Qur'an (TPA).

Dalam proses penyelenggaraannya, majelis taklim ini sangat dipengaruhi oleh kondisi sosial budaya dan ekonomi para jamaah dan ustaz/ahnya. Hal ini nampak dari pemilihan materi pelajaran, proses pembelajaran, dan manajemennya. Materi pelajaran yang dipilih adalah materi utama ajaran Islam pada level dasar. Proses pembelajarannya lebih banyak didominasi oleh guru sebagai sumber belajar tunggal. Manajemen yang diterapkan adalah pola manajemen tunggal, di mana pimpinan merangkap juga sebagai sekretaris dan bendahara majelis taklim.

\section{Referensi}

Alamsyah, Wilayah Kajian Agama di Indonesia, Jakarta: Departemen Agama, 1982 Aly, Hery Neo, Ilmu Pendidikan Islam, Jakarta: Logos, 1999

Dewan Redaksi, Ensiklopedi Islam, Jakarta: Ichtiar Baru Van Hoeve, 2001

Depag, RI, Ensiklopedi Islam, Jakarta, Depag,RI, 1996 
Fontana, Andrea \& James H. Frey.Interviewing: The Art of Science dalam Handbook of Qualitative Research. Norman K.Denzin dan Yvonna S.Lincoln. California: SAGE Publication, Inc., 1994

Hadi, Sutrisno, Metodologi Research, Yogyakarta: Andi Offset, 1990

Jalaluddin, Teologi Pendidikan Islam, Jakarta: Raja Grafinda Persada, 2003

Marimba, Ahmad D., Pengantar Filsafat Pendidikan Idaman, Bandung: al-Ma'arif, 1962

Mappriare, Andi, Psikologi orang Dewasa, Surabaya: Usaha Nasional, 1979

Nawawi, Hadar, Metode Penelitian Bidang Sosial, Yogyakarta: Gajah Mada University Perss, 1993

Notopuro, Hardjito, Peranan Wanita dalam Masa Pembangunan di Indonesia, Jakarta: Ghalia Indonesia, 1979

Puspito, Hendro O.C., Sosiologi Agama, Yogyakarta: Kanisius, 1983

Panin, Panglima, dkk., Pendidikan Orang Dewasa, Jakarta: Departemen Pendidikan, 1997

Nasution, S. Metode Penelitian Naturalistik Kualitatif, Bandung: Tarsito,1992

Saleh, Abd Rahman, Pendidikan Agama dan Keagamaan, Jakarta: Gema Minda Panca Perkasa, 2000

Sarwoto, Dasar-dasar Organisasi dan Managemen, Jakarta: Ghalia Indonesia, 1979

Zulkifli, Psikologi Perkembangan, Bandung: Rajawali Rosda Karya, 2005 